CASSOWARY Volume 2 (2): 106 - 113

ISSN : 2614-8900

E-ISSN : 2622-6545

CProgram Pascasarjana Universitas Papua, https://pasca.unipa.ac.id/

\title{
Daya hasil beberapa varietas Kedelai unggul nasional di Distrik Manokwari Barat dan Sidey Provinsi Papua Barat
}

\author{
The yield of some national Superior Soybean varieties in West Manokwari and Sidey \\ Districts, West Papua Province
}

Agustinus Warbaal, Januarius Renwarin, Nouke L. Mawikere*, Yohanis A. Mustamu

Program Studi S2 Ilmu Pertanian, Program Pascasarjana, Universitas Papua

Jalan Gunung Salju, Amban, Manokwari, Kodepos 98314, Papua Barat, Indonesia.

*Email: lenda_mawikere@yahoo.com

\begin{abstract}
This study aims to examine the yield of 5 national superior soybean varieties in two different locations and select high yielding varieties to be developed in West Papua Province. This research was conducted for four months, which was located in 2 places namely West Manokwari and Sidey District in West Papua Province. The study used a Randomized Block Design with the treatment of 6 varieties (5 national varieties and 1 local variety), which were repeated 4 times so that 24 experimental units per location were obtained. The data obtained were analyzed using analysis of variance (ANOVA) and if the treatment had a significant effect it was continued with the DMRT test at a 95\% confidence level. The results showed that the varieties tested were highly significant for plant height, number of branches, total number of pods, number of empty pods, number of filled pods, weight of planting seeds, weight of seeds per plot, weight of corrected seeds, and weight of 100 dried seeds. The yield of 3 varieties suitable for development in West Papua Province are Rajabasa varieties 1.63 tons/ha, Burangrang 1.8 tons/ha, and Detam-2 2.35 tons/ha.
\end{abstract}

Keywords: Yield, Soybean, Superior varieties, Papua Barat

ABSTRAK: Penelitian ini bertujuan untuk menguji daya hasil 5 varietas kedelai unggul nasional di dua lokasi berbeda serta menyeleksi varietas unggul yang berdaya hasil tinggi untuk dikembangkan di Provinsi Papua Barat. Penelitian ini dilaksanakan selama empat bulan, yang berlokasi di 2 tempat yaitu Distrik Manokwari Barat dan Distrik Sidey Provinsi Papua Barat. Penelitian menggunakan Rancangan Acak Kelompok dengan perlakuan 6 varietas ( 5 varietas nasional dan 1 varietas lokal), yang diulang sebanyak 4 kali sehingga diperoleh 24 satuan percobaan per lokasi. Data yang di-peroleh dianalisis menggunakan analisis ragam (Anova) dan bila perlakuan berpengaruh nyata dilanjutkan dengan uji DMRT pada taraf kepercayaan 95\%. Hasil penelitian menunjukkan bahwa varietas yang diuji berbeda sangat nyata untuk karakter tinggi tanaman, jumlah cabang, jumlah polong total, jumlah polong hampa, jumlah polong isi, bobot biji pertanaman, bobot biji perpetak, bobot biji terkoreksi, dan bobot 100 biji kering. Daya hasil 3 varietas yang cocok untuk dikembangkan di Provinsi Papua Barat yaitu varietas Rajabasa 1,63 ton/ha, Burangrang 1,8 ton/ha, dan Detam-2 2,35 ton/ha. 
Kata kunci: Daya hasil, Kedelai, Varietas unggul, Papua Barat

\section{PENDAHULUAN}

Kebutuhan kedelai terus meningkat dari tahun ketahun sejalan dengan bertambahnya pertumbuhan penduduk. Hal ini disebabkan karena Indonesia merupakan salah satu negara pengkonsumsi kedelai terbesar di dunia. Komoditi kedelai saat ini tidak hanya berfungsi sebagai bahan pangan dan bahan baku industri pangan, namun juga sebagai bahan makanan sehat dan bahan baku industri nonpangan. Secara nasional dalam kurun waktu 5 tahun kedepan (2010 - 2015) rata-rata kebutuhan kedelai adalah 2,3 juta ton biji kering/tahun, sementara kemampuan produksi dalam negeri hanya sebesar 850.286 ton biji kering (37,01\% dari kebutuhan). Rendahnya produksi nasional ini menyebabkan negara harus mengimpor kedelai dari luar negeri untuk mencukupi kebutuhan nasional.

Produksi nasional kedelai berfluktuasi dari tahun ke tahun. Produksi kedelai tahun 2007 diperkirakan sebesar 66.400 ribu ton biji kering. Dibandingkan produksi tahun 2006, terjadi penurunan sebesar 83.17 ribu ton. Tahun 2006 produksi kedelai sebesar 747.60 ribu ton biji kering. Dibanding produksi tahun 2005, terjadi penurunan sebanyak 60.74 ribu ton $(7.51 \%)$. Tahun 2008 hingga 2009 terjadi peningkatan produksi kedelai, masing-masing sebesar 77.57 ribu ton dan 97.29 ribu ton. Ratarata produktivitas kedelai nasional baru mencapai 1.3 ton/ha dengan kisaran 0.62.0 ton/ha di tingkat petani, sementara di tingkat penelitian mencapai 1.73 ton/ha, beragam tergantung pada kondisi lahan/lingkungan. Data pada Dinas Tanaman Pangan dan Hortikultura Provinsi Papua Barat menunjukkan pada tahun 2005 produksi kedelai mencapai 2.279 ton dengan luas panen 2.137 ha.
Penurunan produksi kedelai disebabkan oleh berbagai faktor diantaranya karena penggunaan benih yang produksinya rendah dan juga adanya penurunan luas panen. Tahun 2006 terjadi penurunan luas panen seluas $41.01 \mathrm{ribu}$ hektar, sedangkan tahun 2007 terjadi penurunan luas panen seluas 78.43 hektar (Balitbang Deptan 2007).

Provinsi Papua Barat masuk dalam wilayah pengembangan kedelai nasional untuk menunjang program swasembada kedelai. Hal ini sejalan dengan program pemerintah Povinsi Papua Barat dalam menunjang stabilitas pangan nasional. Untuk itu perlu adanya varietas berdaya hasil tinggi yang dapat dikembangkan diseluruh wilayah Papua Barat. Disamping program di atas $\mathrm{Pa}-$ pua Barat juga memiliki potensi lahan yang sangat menjanjikan sebagai daerah pengembangan sentra produksi kedelai.

Salah satu kendala penanaman kedelai di Papua Barat adalah penggunaan varietas yang daya hasilnya masih rendah. Faktor kualitas benih yang ditanam biasanya menjadi masalah serius yang dihadapi oleh petani, sehingga jumlah optimal produksi tanaman selalu tidak dapat dipenuhi. Untuk itu, upaya perbaikan sistem perbenihan untuk memperoleh benih berkualitas tinggi di tingkat petani masih perlu digalakkan, baik melalui kelompok tani atau pengembangan penangkar benih swasta (Adisarwanto, 2014).

Varietas unggul yang adaptif pada kondisi lingkungan yang berbeda sangat diperlukan untuk peningkatan produksi tanaman. Penggunaan varietas unggul yang sesuai pada lingkungan setempat merupakan salah satu cara terbaik dalam suatu budidaya tanaman. Berdasarkan data dari Direktorat Jendral Tanaman Pangan, Kementerian Pertani- 
an sampai pada tahun 2017 telah melepas sebanyak 92 varietas kedelai yang berdaya hasil tinggi. Keunggulan dari varietas tersebut belum teruji di beberapa daerah, termasuk di Kabupaten Manokwari. Varietas-varietas yang unggul tersebut memiliki kemampuan genetik yang berbeda, dan kemungkinan akan memberikan penampilan fenotipe yang berbeda pula, apabila ditanam pada lingkungan yang berbeda. Untuk itu perlu dilakukan pengujian beberapa varietas unggul nasional, agar dapat diseleksi varietas yang memiliki daya hasil tinggi di Provinsi Papua Barat.

Tujuan penelitian ini adalah untuk menguji daya hasil 5 varietas kedelai unggul nasional di dua lokasi berbeda serta menyeleksi varietas unggul yang berdaya hasil tinggi untuk dikembangkan di Provinsi Papua Barat. Hasil dari penelitian ini diharapkan dapat menjadi sumber informasi bagi petani, pengusaha di bidang pertanian tanaman pangan, dan pemerintah daerah sebagai dasar dalam pengambilan keputusan dan kebijakan dalam pengembangan pertanian di bidang Tanaman Pangan khususnya pengembangan tanaman kedelai.

\section{BAHAN DAN METODE}

Bahan yang digunakan dalam penelitian ini adalah 6 varietas kedelai yang terdiri dari 5 varietas kedelai nasional berdaya hasil tinggi dan satu varietas kedelei lokal Prafi, pupuk, dan pestisida sesuai anjuran. Ke 5 varietas nasional berdaya hasil tinggi yang digunakan yaitu Grobogan, Anjasmoro, Detam-2, Rajabasa, dan Burangrang, sedangkan sebagai pembanding digunakan satu varietas lokal Prafi.

Penelitian dilakukan dengan metode observasi menggunakan Rancangan Acak Kelompok (RAK) 2 faktor. Faktor pertama adalah 6 varietas kede-lai dan faktor kedua adalah 2 lokasi. Masing-masing perlakuan diulang sebanyak 4 kali, sehingga diperoleh 24 satuan percobaan per lokasi. Luas setiap petak percobaan adalah $3 \mathrm{~m} \times 4 \mathrm{~m}$ dan benih kedelai ditanam dengan jarak tanam $30 \mathrm{~cm} \times 40 \mathrm{~cm}$. Pengamatan dilakukan dengan mengambil 12 tanaman contoh yang terpilih secara acak penuh dari tiap satuan percobaan.

Pengamatan dilakukan terhadap komponen pertumbuhan dan komponen hasil tanaman kedelai, meliputi tinggi tanaman, jumlah buku, jumlah cabang, jumlah polong total, jumlah polong hampa, jumlah polong isi, bobot biji/tanaman, bobot biji/petak, bobot biji terkoreksi, dan bobot 100 biji kering.

Data yang diperoleh dianalisis menggunakan analisis varian (Anova) dan bila perlakuan berpengaruh nyata dilanjutkan dengan uji DMRT pada taraf kepercayaan 95\%. Model linier dalam Rancangan Acak Kelompok dengan pola gabungan adalah sebagai berikut (Gomez dan Gomez, 1985):

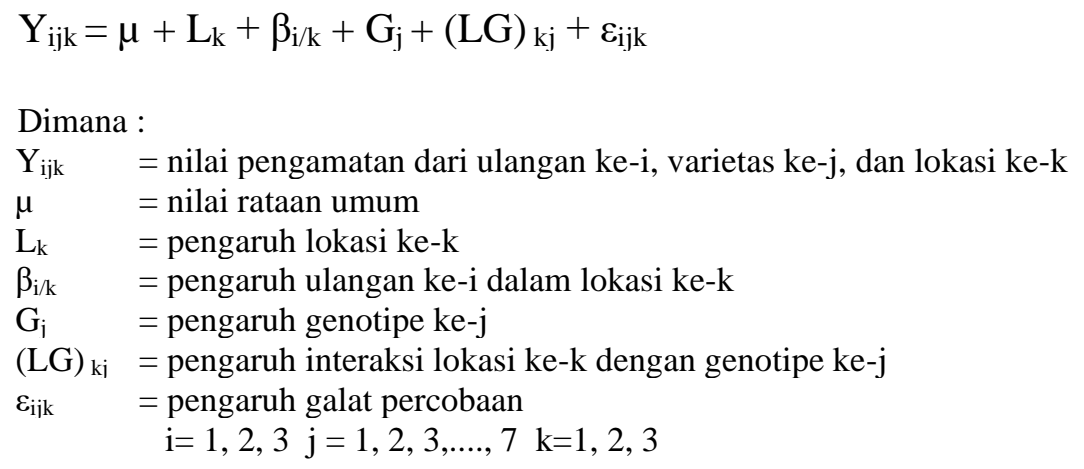




\section{HASIL DAN PEMBAHASAN}

Hasil analisis ragam (Tabel 1) menunjukkan bahwa varietas yang diuji di 2 lokasi dan interaksi antara lokasi dan varietas uji sangat berpengaruh terhadap komponen pertumbuhan dan hasil yang diamati. Karakter-karakter yang memberikan tanggapan yang sangat nyata terhadap lingkungan adalah karakter tinggi tanaman, jumlah cabang, polong total, polong hampa, polong isi, bobot biji per tanaman, bobot biji per petak, bobot biji terkoreksi, dan bobot 100 biji, sedangkan karakter jumlah buku tidak berbeda antara varietas di dalam satu lokasi maupun antara lokasi (Tabel 2). Tidak terdapat perbedaan yang nyata antar varietas yang diuji kemungkinan disebabkan galat percobaan yang besar.

Keragaan karakter-karakter yang sangat nyata antara varietas dan interaksi lokasi $\mathrm{x}$ varietas yang sangat nyata, kecuali untuk karakter jumlah buku, menunjukkan bahwa lingkungan lokasi Amban dan lokasi Sidey memiliki perbedaan yang spesifik. Pertumbuhan tanaman kedelai sangat peka terhadap perubahan kondisi lingkungan tumbuh seperti cahaya, curah hujan, suhu, kesuburan tanah, kondisi fisika dan kimia tanah, dan ketersediaan air dalam tanah.
Tanaman kedelai dapat tumbuh baik pada curah hujan sekitar $300-400 \mathrm{~mm}$ selama musim tanam (Sumarno dan Manshuri, 2007). Suhu yang sesuai untuk pertumbuhan kedelai berkisar antara $22-27^{\circ} \mathrm{C}$. Perkecambahan optimum terjadi pada suhu $30{ }^{\circ} \mathrm{C}$. Ling-kungan optimum kedelai berkecambah setelah empat hari ditanam. Memasuki periode pengisian polong, suhu harian yang baik untuk pertanaman kedelai adalah tidak melebihi $\quad 35 \quad{ }^{\circ} \mathrm{C}$ dengan nis-bah kelembaban yang relatif rendah $( \pm 70 \%)$ (Baharsjah et al., 1985; Sumarno dan Manshuri, 2007). Faktor kesuburan fisika-kimia tanah yang sangat berpengaruh terhadap pertumbuhan tanaman kedelai adalah tekstur, struktur, drainase, kedalaman lapisan olah, $\mathrm{pH}$, kandungan hara, kandungan bahan organik, dan kemampuan tanah menyimpan kelembaban. Komponen kesuburan fisika-kimia tanah tersebut akan berinteraksi dengan faktor lain seperti curah hujan, topografi, dan tinggi tempat yang akan berpengaruh terhadap erosi, ketersediaan air tanah, pelestarian kesuburan lahan, produktivitas lahan dan berkelanjutan produksi (Sumarno dan Manshuri, 2007).

Tabel 1. Rekapitulasi Sidik Ragam komponen pertumbuhan dan hasil varietas kedelai di Distrik Manokwari Barat dan Sidey

\begin{tabular}{|c|c|c|c|c|c|c|}
\hline \multirow{2}{*}{ Karakter } & \multicolumn{2}{|c|}{ Kuadrat Tengah } & \multicolumn{4}{|c|}{ F-hitung } \\
\hline & Varietas & Lok.*var & Varietas & & Lok.*var & \\
\hline Tinggi tanaman $(\mathrm{cm})$ & 426.406 & 393.98 & 9.05 & $* *$ & 8.36 & $* *$ \\
\hline Jumlah cabang & 1.3985 & 1.47 & 4.91 & $* *$ & 5.16 & $* *$ \\
\hline Jumlah buku & 2.0183 & 0.05 & 1.68 & & 0.04 & \\
\hline Jumlah polong total & 653.1172 & 467.45 & 7.53 & $* *$ & 5.39 & $* *$ \\
\hline Jumlah polong hampa & 8.0099 & 9.74 & 4.39 & $* *$ & 5.34 & $* *$ \\
\hline Jumlah polong isi & 639.0202 & 391.84 & 8.28 & $* *$ & 5.08 & $* *$ \\
\hline Bobot biji per tanaman (g) & 60.2945 & 53.79 & 7.37 & $* *$ & 6.57 & $* *$ \\
\hline Bobot biji per petak (kg) & 0.1667 & 0.11 & 6.29 & $* *$ & 4.08 & $* *$ \\
\hline Bobot biji terkoreksi & 0.1521 & 0.09 & 7.93 & $* *$ & 4.49 & $* *$ \\
\hline Bobot 100 biji kering (g) & 126.9253 & 15.86 & 82.58 & $* *$ & 10.32 & $* *$ \\
\hline
\end{tabular}


Analisis selanjutnya memiliki kuasa pengujian yang kuat untuk memperoleh informasi tentang keragaan karakter morfologi, agronomi, daya adaptasi varietas yang diuji pada lingkungan ke 2 lokasi tersebut. Hasil uji lanjutan dengan DMRT tercantum dalam Tabel 2.

Tabel 2 memberikan gambaran bahwa varietas Anjasmoro memiliki tinggi tanaman lebih tinggi dibandingkan dengan varietas Burangrang, Rajabasa, varietas Detam 2 dan varietas Grobogan, namun tidak berbeda dengan varietas lokal Prafi. Perbedaan tinggi tanaman antar varietas dapat disebabkan oleh kemampuan genetik dari setiap varietas dan faktor lingkungan setempat. Karakter tinggi tanaman memiliki nilai heritabilitas rendah $(0,16)$, yang artinya faktor lingkungan di dua lokasi penanaman yang lebih berpengaruh dalam pertumbuhan tinggi tanaman (Mustamu et al., 2015) Faktor lingkungan yang mempengaruhi keragaman tinggi tanaman adalah adanya persaingan antara tanaman untuk memperoleh hara, air dan cahaya, yang mengakibatkan pertumbuhan tanaman di dalam satu varietas dan antara varietas bervariasi. Penampilan tinggi tanaman dari varietas-varietas nasional yang diuji ternyata lebih tinggi dari deskripsinya. Hal ini menunjukkan bahwa respon partumbuhan vegetatif, terutama tinggi tanaman dari varietas-varietas nasional yang diuji sangat baik di lokasi Amban dan Sidey.

Varietas lokal Prafi memiliki jumlah cabang terbanyak dan berbeda nyata dengan varietas lainnya kecuali varietas Detam 2. Varietas lokal Prafi walaupun pertumbuhan tinggi tanamannya lebih rendah dari varietas nasional, namun jumlah cabangnya lebih banyak. Hal ini menunjukkan bahwa pertambahan tinggi tanaman berbanding terbalik dengan pembentukan jumlah cabang, yang artinya makin tinggi tanaman akan menghasilkan jumlah cabang yang makin sedikit, demikian sebaliknya. Kondisi ini dibuktikan dengan hasil analisis korelasi antara tinggi tanaman dan jumlah cabang (Mustamu, et al., 2015) yang bernilai negatif sangat nyata $\left(-0.53^{* *}\right)$.

Tabel 2. Hasil Uji DMRT komponen pertumbuhan dan hasil varietas kedelai di Distrik Manokwari Barat dan Sidey

\begin{tabular}{lccccccc}
\hline Varietas & & Rajabasa & Detam 2 & Burangrang & Grobogan & Anjasmoro & $\begin{array}{l}\text { Pokal } \\
\text { Prafi }\end{array}$ \\
\hline Tinggi Tanaman (cm) & TT & $70.71 \mathrm{bc}$ & $66.89 \mathrm{dc}$ & $72.11 \mathrm{bc}$ & $60.00 \mathrm{dc}$ & $81,58 \mathrm{a}$ & $74.94 \mathrm{ba}$ \\
Jumlah Cabang & JC & $2.69 \mathrm{~b}$ & $3.27 \mathrm{ba}$ & $3.13 \mathrm{~b}$ & $2.69 \mathrm{~b}$ & $2.98 \mathrm{~b}$ & $3.80 \mathrm{a}$ \\
jumlah buku & JB & $8.41 \mathrm{a}$ & $9.59 \mathrm{a}$ & $8.93 \mathrm{a}$ & $8.75 \mathrm{a}$ & $9.59 \mathrm{a}$ & $8.61 \mathrm{a}$ \\
polong total & PT & $56.04 \mathrm{a}$ & $49.92 \mathrm{ba}$ & $45.88 \mathrm{ba}$ & $29.21 \mathrm{c}$ & $42.21 \mathrm{~b}$ & $47.04 \mathrm{ba}$ \\
polong hampa & PH & $4.08 \mathrm{~b}$ & $3.63 \mathrm{~b}$ & $6.00 \mathrm{a}$ & $3.42 \mathrm{~b}$ & $4.71 \mathrm{ba}$ & $3.46 \mathrm{~b}$ \\
polong isi & PI & $52.46 \mathrm{a}$ & $46.79 \mathrm{ba}$ & $40.38 \mathrm{~b}$ & $26.29 \mathrm{c}$ & $38.00 \mathrm{~b}$ & $44.08 \mathrm{ba}$ \\
bobot biji/tanaman $(\mathrm{g})$ & BBT & $15.30 \mathrm{ba}$ & $16.70 \mathrm{a}$ & $18.34 \mathrm{a}$ & $11.22 \mathrm{c}$ & $12.88 \mathrm{bc}$ & $17.29 \mathrm{a}$ \\
bobot biji/petak $(\mathrm{kg})$ & BBP & $0.98 \mathrm{~b}$ & $1.41 \mathrm{a}$ & $1.08 \mathrm{~b}$ & $1.16 \mathrm{~b}$ & $1.15 \mathrm{~b}$ & $1.10 \mathrm{~b}$ \\
bobot biji terkoreksi & BBK & $0.72 \mathrm{~b}$ & $1.11 \mathrm{a}$ & $0.79 \mathrm{~b}$ & $0.79 \mathrm{~b}$ & $0.85 \mathrm{Bc}$ & $0.86 \mathrm{~b}$ \\
bobot 100 biji kering $(\mathrm{g})$ & B100 & $18.45 \mathrm{~b}$ & $15.78 \mathrm{c}$ & $19.16 \mathrm{~b}$ & $26.26 \mathrm{a}$ & $18.08 \mathrm{~b}$ & $15.09 \mathrm{c}$ \\
\hline
\end{tabular}


Rata-rata jumlah cabang yang diperoleh dari hasil penelitian ini lebih sedikit (2.69-3.80 cabang) dibandingkan dengan hasil yang diperoleh di Dsitrik Prafi (Mawikere et al., 2018) yaitu sebanyak (2.74-7.21 cabang). Nilahayati dan Putri (2015) menyatakan bahwa adanya perbedaan jumlah cabang di antara varietas yang diuji disebabkan oleh adanya perbedaan sifat atau keunggulan dari masing-masing varietas sesuai dengan genotipe yang dimilikinya dalam kondisi lingkungan tertentu, sehingga tiap varietas menampilkan sifat dan keunggulannya masingmasing.

Jumlah buku pertanaman antara varietas yang diuji adalah sama, sedangkan jumlah polong total pertanaman menunjukkan perbedaan yang nyata antara varietas uji. Varietas Rajabasa menghasilkan jumlah polong pertanaman terbanyak berbeda nyata dengan varietas Anjasmoro dan varietas Grobogan, tetapi tidak berbeda dengan varietas Burangrang dan varietas Detam 2. Karakter polong isi pertanaman menunjukkan perbedaan yang nyata antar varietas dan varietas Rajabasa menghasilkan jumlah polong isi terbanyak dibandingkan dengan varietas Anjasmoro, varietas Burangrang, dan varietas Grobogan. Jumlah polong yang terbentuk beragam antar varietas, tergantung pada varietas kedelai yang ditanam dan dukungan kondisi lingkungan tumbuh. Dalam hal ini, varietas Rajabasa, Burangrang, dan Detam 2 dapat beradaptasi dengan kondisi lingkungan di 2 lokasi penelitian, sehingga menghasilkan jumlah polong per tanaman dan polong isi terbanyak. Banyaknya jumlah polong per tanaman berkaitan erat dengan jumlah bunga yang ter-bentuk dalam satu tanaman, sedangkan banyaknya jumlah polong isi berkaitan erat dengan banyaknya bunga yang dapat dibuahi sehingga berkembang menjadi biji. Umarie dan Holil (2016) menyatakan perbedaan jumlah polong isi dipengaruhi oleh jumlah bunga yang menjadi buah dan proses fotosintesis pada saat pertumbuhan. Adisarwanto (2014) juga menyatakan pembentukan dan pembesaran polong akan meningkat sejalan dengan bertambahnya umur dan jumlah bunga yang terbentuk.

Varietas Burangrang, varietas Rajabasa, dan varietas Detam 2 menghasilkan bobot biji pertanaman yang sama, tetapi nyata lebih tinggi dari varietas Grobogan dan varietas Anjasmoro. Hasil uji DMRT menunjukkan bahwa varietas Grobogan memiliki ukuran biji yang besar yaitu 26.26 gram/100 biji dibandingkan dengan varietas uji lainnya yang bobot biji per 100 gr berkisar 15,09 - 19.16 gram. Bobot 100 biji memberikan gambaran tentang ukuran biji kedelai. Makin berat bobot 100 biji suatu varietas menunjukkan bahwa ukuran bijinya tergolong besar. Aeni (2014) juga melaporkan bahwa varietas Grobogan memiliki berat kering 100 biji tertinggi mencapai 20,82 gram dibandingkan dengan varietas Anjas-moro, Detam-2, Burangrang, Tangga-mus, dan Lokal Prafi. Tingginya berat 100 biji dipengaruhi oleh kemampuan genetik yang dimiliki oleh varietas ter-sebut. Semakin besar ukuran biji maka semakin tinggi berat biji tersebut. Selain itu, berat 100 biji dipengaruhi oleh ting-kat keringnya biji. Hal ini sependapat dengan Umarie dan Holil (2016) yang menyatakan bahwa berbedanya berat 100 biji disebabkan oleh faktor genetik dan banyak sedikitnya biji kering.

Hasil pengujian terhadap variabel bobot biji perpetak menunjukkan varietas Detam 2 menghasilkan bobot biji perpetak nyata lebih tinggi dibandingkan dengan varietas uji lainnya. Banyaknya biji bernas dan besarnya ukuran biji mempengaruhi berat biji per tanaman dan per petak. Makin banyak 
biji bernas dan makin besar ukuran biji, maka berat biji per tanaman dan per petak akan semakin tinggi. Perbedaan berat biji per tanaman ini juga disebabkan karena faktor lingkungan seperti iklim dan tingkat kesuburan tanah. Umarie dan Holil (2016); Budi (2012), menyatakan bahwa berat biji yang tinggi menunjukkan daya adaptasi yang tinggi terhadap cuaca ekstrim dan kesuburan tanah, sedangkan bobot biji yang rendah menunjukkan bahwa daya adaptasi tanaman semakin rendah terhadap cuaca ekstrim dan kesuburan tanah.

Data rataan bobot biji perpetak di 2 lokasi digunakan untuk memprediksi potensi hasil masing masing varietas yang diuji. Hasil konversi secara linier memberikan gambaran bahwa varietas Anjasmoro, Burangrang, Rajabasa, Detam 2, dan Grobogan berturut turut memiliki potensi hasil di Papua Barat sebesar 1.92 ton/ha, 1.80 ton/ha, 1.63 ton/ha, 2.35 ton/ha, dan 1.93 ton/ha. Produktivitas varietas nasional yang dihasilkan di lokasi Sidey dan Manokwari tergolong masih rendah dibandingkan dengan produktivitas kedelai nasional tahun 2016 ditingkat petani dan ditingkat penelitian. Produktivitas nasional kedelai pada tahun 2016 mencapai 2,56 ton/ha dengan kisaran $0,8-2,4$ ton/ha ditingkat petani, sedangkan ditingkat penelitian mencapai 1,7 - 3,2 ton/ha (Balitbang Pertanian, 2016a).

\section{KESIMPULAN}

1. Varietas-varietas yang diuji pada lokasi Manokwari dan Sidey berbeda nyata untuk karakter tinggi tanaman, jumlah cabang, jumlah polong total, jumlah polong hampa, jumlah polong isi, bobot biji per tanaman, bobot biji per petak, bobot biji terkoreksi, bobot 100 biji kering, sedangkan karakter jumlah buku tidak menun-jukkan adanya perbedaan diantara varietas uji.

2. Varietas Anjasmoro, Burangrang, Rajabasa, Detam 2, dan Grobogan memiliki daya hasil di Papua Barat berturut turut sebesar 1.92 ton/ha, 1.80 ton/ha, 1.63 ton/ha, 2.35 ton/ha, dan 1.93 ton/ha.

\section{DAFTAR PUSTAKA}

Adisarwanto, T. 2014. Kedelai Tropika Produktivitas 3 Ton/ Ha. Penebar Swadaya. Jakarta.

Aeni, E.N. 2014. Pendugaan parameter genetik varietas kedelai (Glycine $\max$ L. Merril) berdaya hasil tinggi pada lahan kering di SP-I, Prafi Manokwari. Skripsi, Fakultas Pertanian dan Teknologi Pertanian, Unipa, Manokwari.

Badan Litbang Pertanian. 2016. Target Nasional Produksi Kedelai 2016 Meningkat.www.litbang.pertanian .go.id/berita/one/2468/. Diakses pada 5 Januari 2018.

Budi, Y. 2012. Uji morfologi daya hasil 5 varietas kedelai (Glycine Max (L.) Merril) berdaya hasil tinggi pada lahan petani di Distrik Sidey Kabupaten Manokwari. Skripsi, Fakultas Pertanian dan Teknologi Pertanian, Unipa, Manokwari.

Direktorat Jendral Tanaman Pangan, 2017. Dirjen TP dan Gubernur Sulteng Buka Gebyar Perbenihan $\mathrm{Ke}-\mathrm{V}$ di Kabupaten Sigi. http://tanamanpangan.pertanian. go.id/berita/197. Diakses pada tanggal 13 Januari 2018.

Mawikere, N.L., Purbokurniawan, A.I. Noya, D. Dare. 2018. Pendugaan Parameter Genetik Delapan 
Varietas Kedelai di kampong Wasegi Distrik Prafi Kabupaten Manokwari. Makalah dipresentasikan pada Seminar Nasional Perhimpunan Pemuliaan Indonesia (PERIPI) Komda Sumatera Barat. 4-5 Oktober 2018. Padang.

Mustamu, A.Y., N.L. Mawikere, Y. Renwarin, A. Warbaal. 2015. Stabilitas Hasil Varietas Kedelai Berdaya Hasil Tinggi di Papua Barat. Prosiding Seminar Nasional Perhimpunan Agronomi Indonesia. Prodi Agronomi Pascasarjana Universitas Sebelas Maret Surakarta. Hal. 609-616.

Nilahayati dan L.A. Putri. 2015. Evaluasi Keragaman Karakter Fenotipe Beberapa Varietas Kedelai
(Glycine Max L.) di Aceh Utara. Jurnal Floratek 10(1):36-45.

Sumarno dan A.G. Manshuri. 2007. Persyaratan tumbuh dan wilayah produksi kedelai di Indonesia, hal 74-103. Dalam Sumarno, Suyamto, A. Widjono, Hermanto, H. Kasi $(E d s)$. Kedelai, Teknik Produksi dan Pengembangan. Badan Penelitian dan Pengembangan Pertanian. Bogor.

Umarie, I dan M. Holil. 2016. Potensi Hasil dan Kontribusi Sifat Agronomi Terhadap Hasil Tanaman Kedelai Pada Sistem Tumpang Sari Tebu-Kedelai. Agrotop Jurnal Ilmu-Ilmu Pertanian. Fakultas Pertanian Universitas Muhammadiyah. Jember Hal 1-11. 